\section{RECORD OF FULVOUS LEAF-NOSED BAT HIPPOSIDEROS FULVUS GRAY, 1838 FROM JAMMU AND KASHMIR, INDIA}

Zoological Survey of India, High Altitude Zoology Field Station, Saproon, Solan, Himach Pradesh 173211, India

Fulvous Leaf-nosed Bat Hipposideros fulvus Gray, 1838 (Chiroptera: Hipposideridae) is a medium- to small-sized bat with characteristically very large ears (Bates \& Harrison, 1997; Roberts, 1977). The average forearm length of $40.4 \mathrm{~mm}$ distinguishes it externally from closely resembling species $H$. ater Templeton, 1848 in which average forearm length is $36.3 \mathrm{~mm}$ (Bates \& Harrison, 1997). The pelage colour is variable including dull yellow, pale grey, dull brown and golden orange (Brosset, 1962). This species is endemic to the Indian subcontinent except for a marginal population in eastern Afghanistan as reported by Gaislar (1970). The recorded distribution of this species in India includes Haryana, Uttar Pradesh, Bihar, Madhya Pradesh, Rajasthan, Gujarat, Maharashtra, Karnataka, Tamil Nadu, Kerala, Orissa, Nicobar Island and perhaps absent in the North East (Bates \& Harrison, 1997; Hill et al., 1986). The population of this species seems to be contiguous throughout the distributional range except for Nicobar Island (Molur et al., 2002).

We would like to report the occurrence of this species in the state of Jammu and Kashmir based on a specimen (Regn. No. M-2) present at the museum collection of the High Altitude Zoology Field Station, Zoological Survey of India (ZSI), Solan, Himachal Pradesh. An adult male was collected from its day roost in a natural cave, c. $2 \mathrm{~km}$ west of Mansard lake $\left(32^{\circ} 48^{\prime} \mathrm{N} \&\right.$ $75^{\circ} 23^{\prime} \mathrm{E}$, c. $450 \mathrm{~m}$ ) in Jammu district by a ZSI survey team lead by Dr. H. Khajuria in October, 1978. A few individuals of the same species were also observed roosting in the cave. The cave was located on a slope surrounded by Pinus longifolia. Presence of porcupine (Hystrix sp.) quills in the area was also observed. Roberts (1977) mentions that in Pakistan, this bat is known to prefer open burrows of porcupine as day roost.

The alcohol preserved specimen is brownish dorsally with greyish hair roots and venter creamy with grey tinge. The noseleaf is squarish and devoid of any subsidiary lateral leaflets. The third metacarpal $(30.2 \mathrm{~mm})$ is shorter than the fifth $(30.7 \mathrm{~mm})$. The ear is very large $(20 \mathrm{~mm})$ compared to the overall body size of $43 \mathrm{~mm}$. The skull was taken out and all cranial measurements were taken using a dial caliper. After examining the morphological and cranial characters, which fit well into the character matrix given by Bates and Harrison (1997), it was determined to be $H$. fulvus. The morphological and cranial measurements of the specimen are given below.

Head Body (HB) - 43mm; Tail (T) - 25mm; Hind Feet (HF) - 7.6mm; Ear (E)-20mm; Fore Arm(FA)-40.3mm; Tibia(TIB)-20mm; Third Metacarpal (4mt) - 31.2mm; Fifth Metacarpal (5mt) - 30.7mm; Greatest length of

\section{Uttam Saikia, R.M. Sharma and D.K. Sharma}

skull (GTL) - 18.2mm; Condylo-basal length(CBL) - 16.3mm; Condylocanine length (CCL) - 15.6mm; Maxillary toothrow $\left(\mathrm{CM}^{3}\right)$ - 6.5mm; Posterior palatal width $\left(\mathrm{M}^{3}-\mathrm{M}^{3}\right)$ - 7mm; Breadth of braincase $(\mathrm{BB})$ 8.1mm; Postorbital constriction (PC) - 2.7mm; Zygomatic breadth (ZB) - 9.4mm; Anterior palatal width $\left(\mathrm{C}^{1}-\mathrm{C}^{1}\right)-4 \mathrm{~mm}$; Mandible $(\mathrm{M})$ - 11.5mm; Mandibular toothrow $\left(\mathrm{CM}_{3}\right)-7.1 \mathrm{~mm}$.

Within the Indian limit, the northernmost recorded distribution of the species is Hissar $\left(29^{\circ} 10^{\prime} \mathrm{N} \& 75^{\circ} 45^{\prime} \mathrm{E}\right)$ in Haryana (Siddiqi, 1961). The number of species of bats recorded earlier from Jammu and Kashmir (including Pakistan Occupied Kashmir) was 28 (Bates \& Harrison, 1997) and this report increases the total to 29. However, this is a single record and more surveys are required to determine its presence in other parts of the state.

Taxonomic remark: Specimens from northern India and Pakistan are assigned to $H$. $f$. pallidus on accout of their paler dorsal pelage (Roberts, 1977; Corbett \& Hill, 1992; Bates \& Harrison, 1997).

\section{Conservation status:}

Least Concern (LC) (South Asia) Molur et al. (2002)

Lower Risk least concern (LRlc)(Globally) Hutson et al. (2001)

\section{REFERENCES}

Anderson, K. (1918). Diagnoses of new bats of the families Rhinolophidae and Megadermatidae. Annals and Magazine of Natural History 2: 374-384.

Bates, P.J.J. and D.A. Harrison (1997). Bats of the Indian Subcontinent. Harrison Zoological Museum, 258pp.

Brosset, A. (1962). The bats of western and central India. Part II. Journal of the Bombay Natural History Society 59(2): 583-624.

Corbet, G.B. and J.E. Hill (1992). The Mammals of Indo-Malayan Region A Systematic Review. Natural History Museum/Oxford University Press, 488pp. Gaisler, J. (1970). The bats (Chiropetra) collected in Afghanistan by the Czechoslovak Expedition of 1965-1976. Acta. Sc. Nat. Acad. Sci. Bohemoslovacae 4(6): 1-56.

Gray, J.E. (1838). A revision of the genera of bats. Magazine of Zoology and Botany 2: 483-505.

Hill, J.E., A. Zubaid and G.W.H. Davidson (1986). The taxonomy of the leaf-nosed bats of the Hipposideros bicolor group (Chiroptera: Hipposideridae) from Southeastern Asia. Mammalia 50(4): 535-540

Hutson, A.M., S.P. Mickleburgh and P.A. Racey (compilers) (2001). Microchiropoteran Bats: Global Status Survey and Conservation Action Plan. IUCN/SSC Chiroptera Specialist Group. IUCN, Gland, Switcherland and Cambridge, UK, 258pp.

Roberts, T.J. (1977). The Mammals of Pakistan. Ernest Benn Limited, London \&Tonbridge, 361pp.

Siddiqi, M.S. (1961). Checklist of mammals of Pakistan with particular reference to the mammalian collection in the British Museum (Natural History), London. Biologia 7(1-2): 93-225.

Molur, S., G. Marimuthu, C. Srinivasulu, S.A. Mistry, A.M. Hutson, P.J.J. Bates, S. Walker, K. Padma Priya and A.R. Binu Priya (Eds) (2002). Status of south Asian Chiropetra: Conservation Assessment and Management Plan (C.A.M.P.) Workshop Report. Zoo Outreach Organisation. CBSG South Asia \& WILD, Coimbatore, India, vii+141pp+CD-Rom.

Templeton, W.E. (1848). In Blyth, E., Report of curator. Journal of the Asiatic Society Bengal 17: 247-255.

\section{ACKnowledgement}

We are grateful to Dr. J.RB. Alfred, Director, Zoological Survey of India, Kolkata, and Dr. Arun Kumar, Addl. Director, NRS, ZSI, Dehradun for constant encouragement and necessary facilities; to Dr. M.S. Pradhan, Jt. Director, WRS, ZSI, Pune for reviewing the manuscript and suggesting necessary corrections. 